\title{
Cost risk of construction of small hydroelectric power plants
}

\author{
Jarosław Górecki ${ }^{1, *}$, Ewa Ploszaj ${ }^{2}$ \\ ${ }^{1}$ UTP University of Science and Technology, al. prof. S. Kaliskiego 7, 85-796 Bydgoszcz, Poland \\ ${ }^{2}$ HYDRO-EKO Sp. z o.o., ul. Inwalidów 3i, 85-749 Bydgoszcz, Poland
}

\begin{abstract}
The growing demand for electricity forces the humanity to find the most economical methods of its production. Functioning without electricity in today's world deprives human from the possibility of a free existence, and even completely prevents it because of the technicisation of society. Growing awareness of acquiring "clean" environmentally-friendly energy from renewable sources contributes to the successive development of this sector of the economy. The purpose of the article was to analyse the risk of construction costs for small hydroelectric power plants along with an indication of the location and needs of a small hydroelectric power plant in Poland. The subject of the study was a small hydroelectric power plant producing electricity, using a turbine to convert the kinetic energy of water into mechanical energy. Aiming at illustrating the benefits of the discussed investment based on the estimation of construction costs and, as a result, financial results, a specific case of a small hydroelectric power plant located in the region of Kujawsko-Pomorskie [Kuyavian-Pomeranian Viovodeship] in central Poland was analysed. The intended research objective was achieved using industry literature, magazines as well as technical knowledge of persons holding building qualifications (including hydro-technical construction) and materials made available by two Bydgoszcz companies specializing in the implementation of small hydroelectric power plants. The COMAR-Jarek Górecki ${ }^{\circledR}$ algorithm, which operates in the industry as the author's concept of calculating the variation of financial outlays incurred for the implementation of investment and construction projects, was used to analyse the risk of costs of a construction project.
\end{abstract}

\section{Introduction}

Small hydroelectric power plants as energy plants are considered an alternative to fossil fuels, as well as to controversial nuclear power plants. In the light of the law, they belong to objects that can potentially significantly affect the environment.

However, due to the production of energy in an ecological way, they contribute to the protection of nature. In addition to the benefits of the method of generating electricity, they have a number of other advantages, discussed in more detail in this study. Poland as a lowland country, poor in water marginalizes the need to build small hydroelectric power plants without being aware of the consequences of such proceedings. Hence the need to educate and raise public awareness about the benefits of energy production using small hydroelectric power plants. Nowadays, supplying electricity to homes is a prerequisite for free functioning. It causes the necessity of determining the place and the needs of its production by alternative energy sources, for example a small hydroelectric power plant.

Today, the major obstacle to investing in small hydroelectric power plant project is a concern of how much it will cost [1]. Moreover, there are possible deviations between cost estimations and actual cost of existing plants commissioned [2]. Sometimes, parametric estimations turn out to be more accurate [3].
The aim of the research is to estimate the level of risk related to the costs of construction of small hydroelectric power plants calculated in a traditional, bottom-up, way, and to show that besides financial profits for the investor they bring a number of other benefits, such as the production of "clean" electricity. This should encourage decision-makers at national and European level to support this type of projects that protect the natural environment and limit their negative impact by reducing the emission of carbon dioxide and other harmful substances.

The above statements allow to formulate the following research hypothesis: "Observation of the benefits of the construction of a small hydroelectric power plant, being a project with a relatively high level of cost risk, is possible only under the condition of having great patience, financial resources and technical knowledge." It will be explored in the course of this study.

By: "patience" should be understood the ability to wait for the result of investment actions undertaken in the long-term perspective; "financial resources" are the capital resources available that could cover the implemented project; "technical knowledge" is an asset of acquired theoretical and practical skills as well as experience as a result of many years of implementation practice.

Corresponding author: gorecki@utp.edu.pl 


\section{The context of the construction of small hydroelectric power plants}

Nowadays, a huge demand for energy is inextricably linked to free living, thus putting society in the position of its slaves. The solar energy accumulated on earth allows the use of fossil fuels - as primary carriers - in the form of crude oil, natural gas, lignite and hard coal as well as peat - resulting from the partial decomposition of organic substances over recent geological eras. As a result of the transformation of the primary product, a secondary carrier is obtained, for example, petrol from oil, coke from coal or electricity from a thermal power plant [4].

Apart from conventional energy, which should be understood as the use of previously discussed nonrenewable sources in the field of fossil fuels, it is possible to distinguish unconventional energy, i.e. derived from renewable sources. Its essence is the use of renewed - as a result of the solar energy inexhaustible for millions of years - energy carriers: solar, wind, watercourses and biomass.

Favourable climatic, water and geological conditions contribute to the use of renewable energy sources (hereinafter referred to as RES) by individual countries. The policy of a "green" country, that is to a small extent using conventional energy, supports the global protection of the environment. The development of this sector of the economy also allows for energy security. Among the common methods of obtaining energy from RES the following ought to be distinguished, among others: solar energy characterized by huge dispersion and resources, but which, due to the relatively high cost of energy conversion installations, occurred to be of low profitability, wind power generating electricity using high-noise turbines, biomass energy characterized by obtaining energy from waste incineration with the release of relatively harmless and small amounts of substances into the atmosphere, water energy widely considered to be the most efficient and stable source of all the above.

The continuous circulation of water in nature is possible due to solar radiation. Under the influence of heat supplied to the globe, water evaporates from plants, the surface of the ground, as well as from surface water into the atmosphere [5].

Due to the condensation of water vapour caused by the mixing of air masses and lowering of temperature, small drops of water after combining with each other fall in the form of atmospheric precipitation (rain and snow). Precipitation water reaching the surface of the earth feeds, among others, watercourses joining the rivers, which then evaporate, thus creating a water cycle in nature. The energy potential of flowing water in the form of potential energy is used in hydroelectric power plants to generate electricity.

Small hydroelectric power plants (hereinafter referred to as SHPP) with installed capacity up to $5 \mathrm{MW}$ (megawatts) belong to hydrotechnical facilities. Their basic division is shown in Figure 1.

The dependencies between individual hydrotechnical objects included in the comprehensive project of construction of a small hydroelectrical power plant are shown in the Figure 2 and Figure 3.

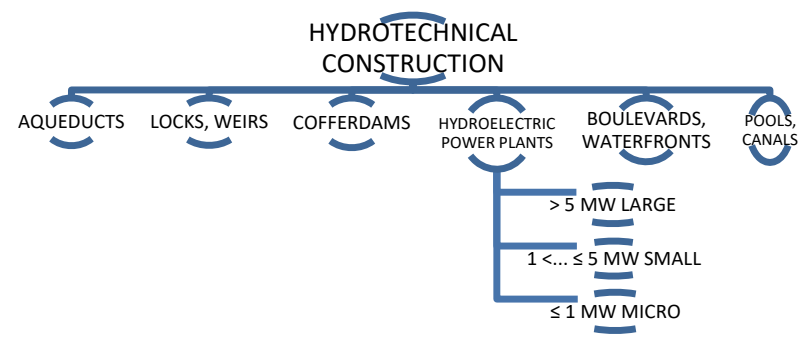

Fig. 1. Division of hydrotechnical constructions

In the first case, the buildings were constructed on the canal of Kanał Górnonotecki (Kuyavian-Pomeranian) Voivodship, and in the second on the Lupawa river, the lock (Pomeranian Voivodship). Lock (Figure 2, designation: " $\star$ ") was built to allow vessels to overcome differences in water levels. Weir together with dam (figures 2 and 3, designation: ") as a damming construction - maintaining permanent or temporary damming up of water - it divides a natural or artificial canal of the watercourse [6]. Small hydroelectrical power plant sensu stricto (figures 2 and 3, designation: " "), whose "heart" is the water turbine, processing the accumulated water, secures the energetic needs of the local community.

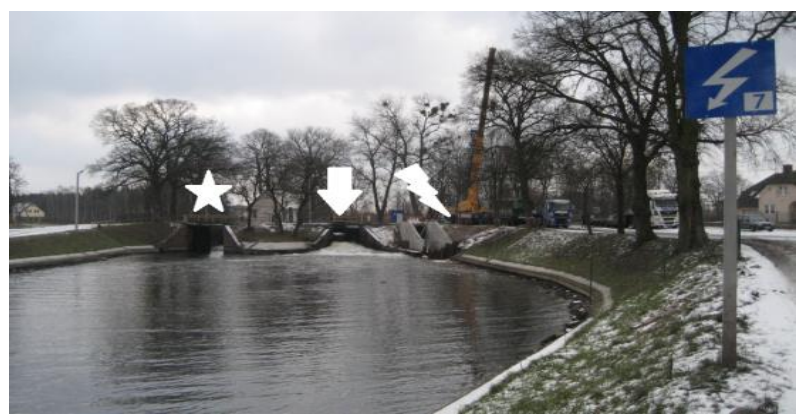

Fig. 2. Construction of the Small hydroelectric power plant Łochowo.

Source: Archives of Przedsiębiorstwo Budownictwa Hydrotechnicznego "HYDRO-EKO" Sp. z o. o.

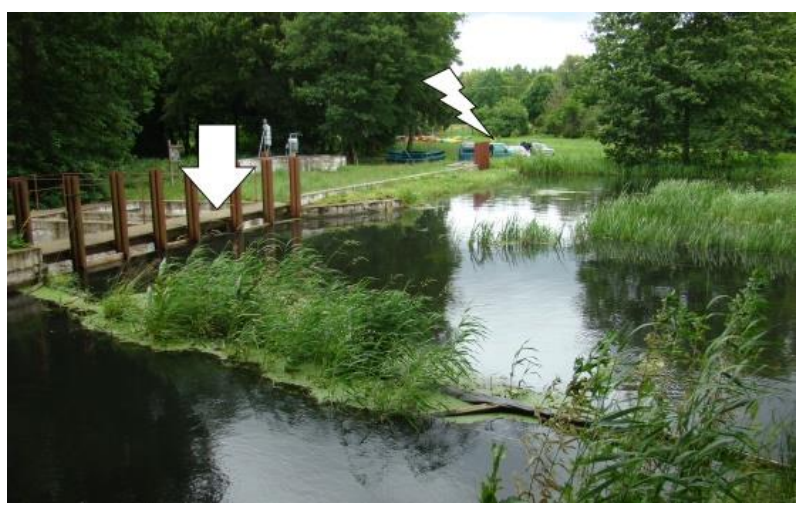

Fig. 3. The existing weir dam $2 \mathrm{~J}$ Kozin at $\mathrm{km} 70+300$ of the Łupawa river in Kozin, the municipality of Czarna Dąbrówka and the closed small hydroelectric power plant. Author: Jarosław Górecki 
A detailed breakdown of SHPP is illustrated in Figure 4.

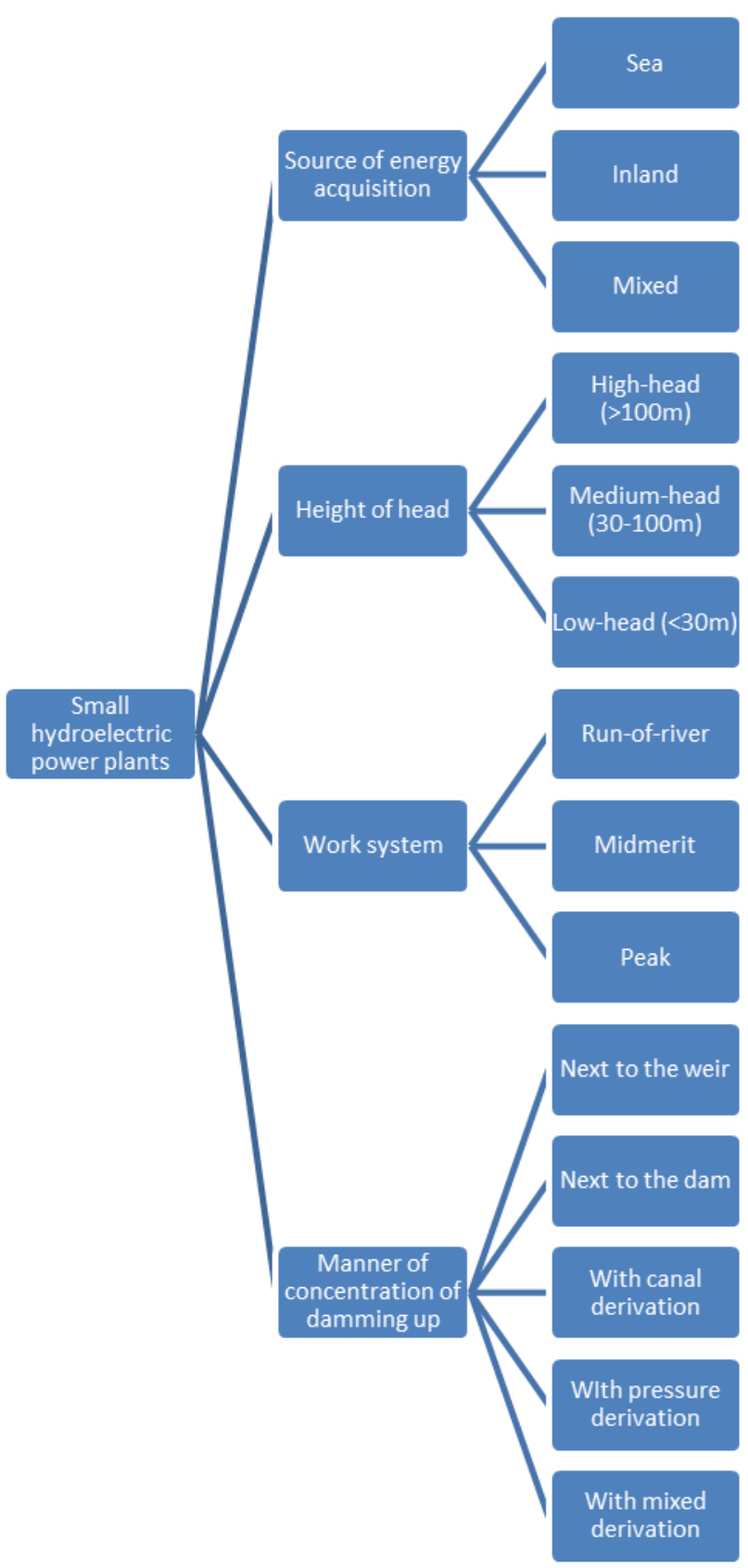

Fig. 4. Division of small hydro power plants

The most commonly used solution due to the economic aspects and location is acquiring power from power plants located in inland waters. An important role in estimating the construction costs of the discussed project is played by the height of the head. It is one of the basic parameters for the selection of a turbine being the "heart" of each SHPP. The value of the head is variable depending on the seasons (atmospheric precipitation) and water conditions. This determines the measurements before proceeding to the design of the object [7].

Small hydroelectric power plants, next to the main task of producing electricity, are used for water management. They play an important role in stabilizing water relations, flood protection, and also contribute to the improvement of surface water retention and aeration.
Each construction project brings a number of tangible benefits, but it should be remembered that it also significantly affects the environment and the local community. A series of thoughts on the construction of small hydroelectric power plants are presented below.

\subsection{Advantages}

The basic characteristics of the construction of SHPP listed both by its supporters and opponents is the production of so-called "clean" energy [8]. This term was adopted due to the fact that during the generation of electricity from renewable sources, no harmful substances are emitted into the atmosphere in the form of: $\mathrm{CO} 2, \mathrm{NOx}, \mathrm{SO} 2$, as is the case in coal-fired power plants. In addition, dust and solid waste, significantly polluting the environment, is a negative consequence of conventional energy processes [9]. The small hydropower industry actively contributes to saving primary energy carriers such as: hard coal, lignite and natural gas [8]. Currently, the Polish energy industry is mainly dominated by traditional methods of obtaining energy, the consequence of which - next to the emission of harmful substances into the atmosphere - is the shrinking of fossil fuel deposits.

Small hydroelectric power plants are also important from the point of view of ensuring micro-retention, especially needed for agriculture [10]. Its aim is to improve the moisture conditions of the areas located near the SHPP. In addition, it increases the diversity of the environment and landscape, and contributes to flood and fire protection.

Another aspect for the need to build the SHPP is its participation in water aeration. In general, this contributes to the improvement of the biological condition of waters [9]. This process involves additional air supply of the watercourse, as a result of its accumulation. The oxygen supplied in it, as the basic component of life, allows fauna (especially fish) proper existence. In addition, by reacting with organic material, it decomposes it, thus naturally purifying water.

An additional asset of the SHPP is the purification of water from waste that is not decomposed. Protective grates being a standard element of power plant equipment, mounted at their inlet, protect the turbines from damage caused by garbage flowing with the stream's current. In order to ensure the proper functioning of the devices, it is necessary to constantly remove excess waste accumulating on the grates, while improving the quality of the water.

Small hydropower plants among unconventional energy specialists are considered to be the source of the least energy for own work among all known methods of its production. In terms of percentage, SHPP use $0.5-1 \%$ of the generated energy to meet the needs, and in the case of thermal power plants, the amount is much higher, as it is about $7-8,5 \%$. It should also be added that the coal mining itself takes place using energy resources. This demand is estimated at approx. $7 \%$ of the production value of the whole power plant [7]. 
An equally important advantage is the high efficiency of SHPP, which means low transmission losses of the generated current. Energy production in a distributed system (a lot of small objects generating electricity located in a given area) guarantees the supply of electricity to the recipient with a negligible loss, due to its close location from the source of production.

An important issue for the local community and the economy are financial revenues from tourism and recreation provided with the participation of SHPP [11]. The facilities of small hydroenergy industry are attractive in the aspect of landscape architecture and technology, which may constitute an unusual tourist attraction.

\subsection{Disadvantages}

The basic disadvantage, most often mentioned by the opponents of the construction of small hydroelectric power plants, is their negative impact on the deepening of water (bottom) erosion, in particular below the water level [8]. This process consists in shifting elements of the bottom of watercourses, due to the action of water currents. This means the formation of cavities in the ground. Another common objection to SHPP is cutting the continuity of the river as a result of their construction. According to ecologists, this leads to irreversible changes in the biodiversity of the ecosystem. That is why it is extremely important to design this type of facilities, taking into account the need to erect socalled passes, i.e. river structures or devices used at water levels, designed to allow fish to wander along the river, which is especially important during spawning.

The last disadvantage caused by hydroelectric objects, present in Poland due to climatic conditions, is the obstruction of ice flow. In winter, watercourses freeze preventing continuous and free operation of small hydroelectric power plants. The ice floe flowing with the current of the river encountering an obstacle on the way stops on it, creating a blockage. In this way, SHPP actively contributes to the obstruction of ice flow. Ice floe deposits are a significant hindrance, inter alia, for navigation, because they completely prevent or disrupt its free passage along the river. It is important to take into account the need to eliminate ice jams with the help of specialized floating equipment (so-called icebreakers).

\section{Characteristics of the undertaking}

The small hydroelectric power plant (SHPP) Lisi Ogon (Figure 5) served as the basis for further consideration. The cost analysis was made possible thanks to the information provided by the investor and the contractor for this task.

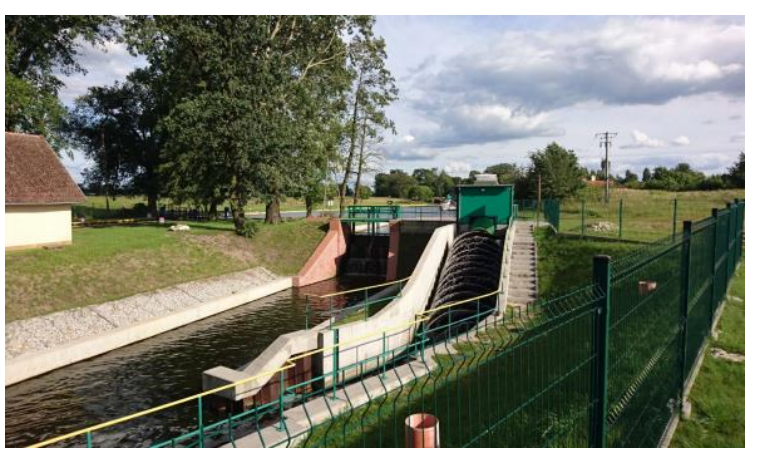

Fig. 5. SHPP Lisi Ogon from the bottom of the water. Author: Ewa Płoszaj

\subsection{Design assumptions}

The facility is located in Poland on the Kanat Górnonotecki Canal in Łochowo, Białe-Błota municipality, Bydgoski district, Kuyavian-Pomeranian province, in the immediate vicinity of the Lisi Ogon water barrage. Pursuant to the Regulation of the Minister of the Environment of 20 April 2007 on technical conditions to be met by hydrotechnical constructions and their location, it was classified as class IV hydrotechnical constructions. According to the design assumptions, the average annual production of SHPP Lisi Ogon is about $400,000 \mathrm{kWh}$ in the period from March to November, i.e. in the time anticipated as the damming period of Lisi Ogon weir. The remaining months due to the winter period and the predominantly low temperatures are not forecasted as the working time of the power plant, however, production under favourable weather conditions is not excluded. SHPP Lisi Ogon has been designed as a run-of-river power plant, collecting $3.2 \mathrm{~m} 3 / \mathrm{s}$ of water on average, and then discharged in an analogous amount, $45 \mathrm{~m}$ from the place of its collection. The required minimum water flow for the analysed object is $0.6 \mathrm{~m} 3 / \mathrm{s}$, while the maximum is $8.8 \mathrm{~m} 3 / \mathrm{s}$ with the proviso that at this value the efficiency parameters of the test object are automatically reduced. The expected height of the head ranges from $3.07 \mathrm{~m}$ $3.17 \mathrm{~m}$ depending on the level of water flowing through the damming stage. The SHPP Lisi Ogon facility operates thanks to the use of the Archimedes turbine with a diameter of $2,800 \mathrm{~mm}$, a length of $8,400 \mathrm{~mm}$, a tilt angle of $21^{\circ}$ and a number of 25 revolutions per minute.

\subsection{The result of the undertaking}

The total cost of construction completed in 2014-2015 determined on the basis of a cost estimate made available by the investor was PLN 1,564,560.00. In order to finance the project, the investor applied for cofinancing from the European Regional Development Fund. The received support amounted to PLN 647,700.00. Therefore, to cover the other costs, the investment loan was used. The result of the project is shown in Figure 6. It depicts the erected structure as a result of the construction works performed. 


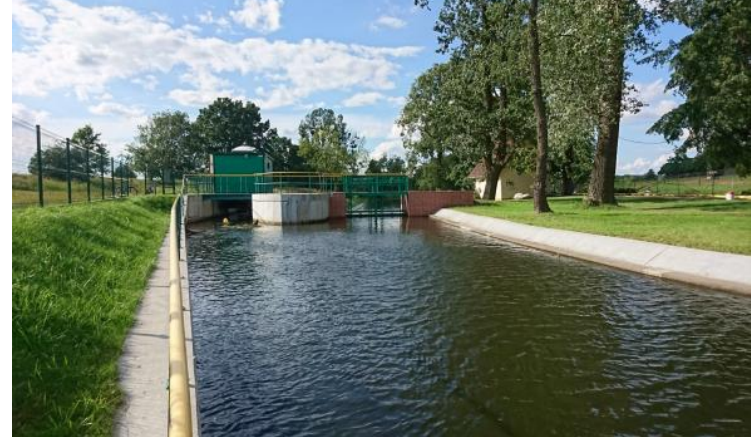

Fig. 6. SHPP Lisi Ogon from the upper side. Author: Ewa Płoszaj

The above-mentioned cost includes construction works, along with the purchase of materials and turbines as well as control room equipment, without taking into account the costs incurred for the preparatory stage in the form of completing the documentation and obtaining the necessary permits. The formal and legal process was estimated by the investor in the amount of PLN 50,100.00, which determines the level of expenditures incurred for the implementation of the construction project at the level of PLN 1,614.660.00.

\section{Evaluation perspectives}

The profitability of building a small hydroelectric power plant is associated mainly with financial issues [12]. However, the authors would like to extend the approach to the impact assessment of the implemented investment and pay attention to the fact that the financial outlay and return on investment is not the only condition for the construction of a small hydroenergy facility. Surely, every investor who wants to build a small hydro power plant is interested mainly in projected investment income, especially in the context of the shortest period of return on investment. However, it should be borne in mind that a small hydropower facility is closely related to nature conservation issues, therefore, considerations on the appropriateness of construction of such facilities should be carried out in the context of assessment of environmental impact throughout the entire life cycle of a structure. A broad perspective on the profitability of investment allows us to document the need for its implementation, and thus the need to educate the public in the field of environmental protection, as well as the energy security and independence of Poland. The profitability perspectives presented below together with the description, support, stress, but in particular underline the advantages of the SHPP presented earlier.

\subsection{Economic}

On the basis of the construction documentation collected, as well as updating the cost estimate prepared for the construction purpose, it should be stated that the estimated cost estimate increased in August 2017 to approximately two million two hundred thousand PLN. The updated cost estimate used price lists of construction production factors from 2017. An absolute comparison of individual components of the price was also made, the results of which are presented in the table below.
Table 1. Change of individual components of the cost estimate for the construction of SHPP Lisi Ogon.

\begin{tabular}{|c|c|}
\hline Element & Change \\
\hline Direct labour costs & $+40 \%$ \\
\hline Direct costs of materials & $+18 \%$ \\
\hline The direct costs of equipment work & $+12 \%$ \\
\hline
\end{tabular}

\subsection{Ecological}

The environmental benefits of electricity production using renewable energy sources are invaluable. In particular, no emissions to the atmosphere of harmful substances in the form of $\mathrm{CO} 2, \mathrm{NOx}, \mathrm{SO} 2$, or a reduction in the production of solid waste and harmful to the health and lives of citizens, and also purification of water from impurities, as well as its aeration are the aspects that contribute to the promotion of acquiring energy in hydroelectric power plants. Respecting the environment treated as the surrounding of building structures will allow for extending life on earth, and will also facilitate the free functioning of future generations. Ecological profitability is also an improvement in the existence of fauna and flora. Smog settling on plants hinders the process of photosynthesis thanks to which oxygen is produced on Earth. Although the abovementioned aspects are well known and belong to the socalled general knowledge, downplaying and marginalizing thereof is evident in everyday life. Care for the environment, clean atmosphere and air can be achieved, among others, by using small hydropower plants, hence the need for education and promoting the advantages of hydropower. To sum up, ecological profitability is a profit in the form of a healthy and longlived society and all earthly creatures, it is clean water and air, it is the protection of natural heritage and primary energy carriers, and finally care for the uncontaminated existence of future generations.

\section{Analysis of the risk of costs of a construction project}

The specificity of construction works means that many factors affecting the final costs cannot be accurately predicted. The variability of the technological and organizational conditions for the construction of buildings results in deviations from the planned construction costs. Predicting construction costs of investment projects is an important risk area for this type of venture. The cost risk can be considered from the perspective of individual participants of the undertaking. Particular emphasis requires a source of cost risk related to the investor and contractor of construction works.

For the needs of the cost analysis of a construction project, the approach described in more detail in the literature [13] has been applied. It used observations about the random nature of individual cost-generating 
factors. The essence of the analysis is to calculate the cost of the SHPP project Lisi Ogon as a function of reliability and hence the risk of estimation. It will allow to create curves of contingency of the cost of construction projects depending on the form of factors shaping their calculation value (types of distributions of values of these factors and their parameters). Probabilistic cost prediction with risk analysis will allow predicting the level of construction costs risk at a high level of reliability. The proposed method of determining the risk value of construction projects costs in the planned time horizon, based on the calculated value and probability of its preservation, will allow to increase the accuracy of the budgeting of construction investment projects. This is one of the significant determinants of the success of these ventures, as previously described [14]. The construction of the cost model for a construction project was based on the formula for cost estimation of construction works described in the formula 1 .

$$
C=L+M+E+R_{\mathrm{IC}} *(L+E)+R_{\mathrm{P}} *\left[L+E+R_{\mathrm{IC}} *(L+E)\right]
$$

where:

$L$ - value of labour [PLN],

$M$ - value of materials together with purchase costs [PLN],

$E$ - value of equipment work [PLN],

$R_{\mathrm{IC}}$ - indirect cost mark-up ratio [\%],

$R_{\mathrm{P}}$ - profit mark-up ratio [\%].

The construction of SHPP Lisi Ogon according to the cost estimate would amount to PLN 2,160,589.92 in 2017, or PLN 1,756,577.17 net (cost estimate of the investment). Assuming the cost structure as in Figure 7, data were entered into the COMAR - Jarek Górecki simulation program.

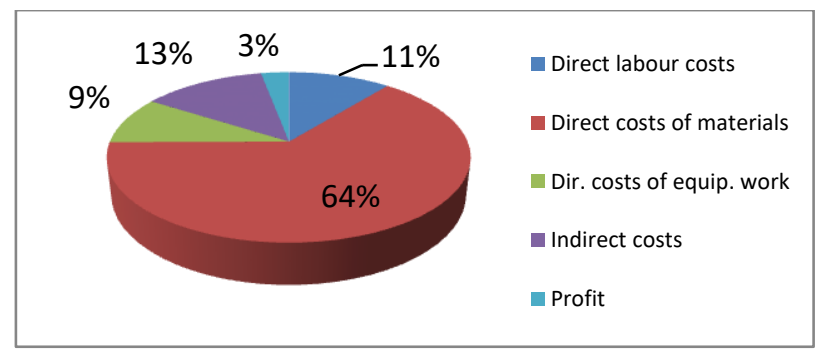

Fig. 7. Structure of the cost estimate value of SHPP Lisi Ogon construction, 2017. Own study

The following expert-based distributions have been adopted for individual parameters:

- value of labour: normal distribution (expected value: PLN 191,048.72, standard deviation: 19.104,87 PLN),

- material value: triangular distribution (PLN 1,073,878.63, PLN 1,124,386.00. 1,174,983.37 PLN),

- value of equipment work: normal distribution (expected value: PLN 160.461,83, standard deviation: 4,813.85 PLN),

- indirect cost mark-up ratio: fixed value: 0.65 .

- $\quad$ profit mark-up ratio: fixed value: 0.09 .
The program has performed 30,000 iterations, as a result of which the histogram of the project costs shown in Figure 8 was constructed.

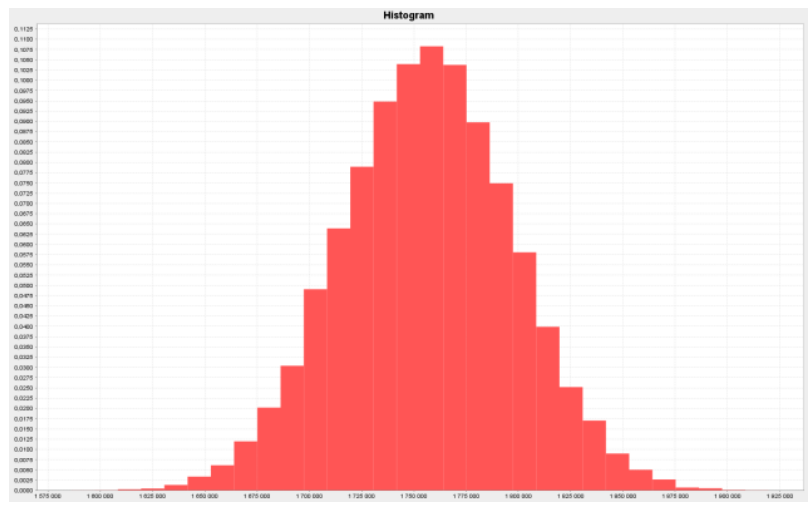

Fig. 8. Probability distribution of the project costs of SHPP Lisi Ogon construction, 2017. Own study

Distribution of the simulation of the value of the costs of the SHPP project for Lisi Ogon is presented in Figure 9.

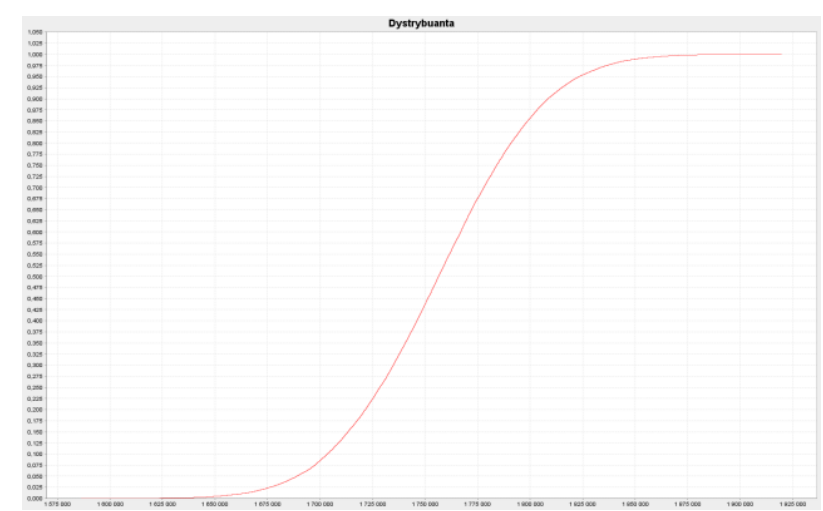

Fig. 9. Cumulative distribution of the project costs of SHPP Lisi Ogon construction, 2017. Own study

The results of the simulation performed:

- deterministic value: 1,756,577.17 PLN),

- number of values less than the deterministic value: 15047 ,

- median: 1,756,419.61 PLN),

- reliability: $50.2 \%$

- risk: $49.8 \%$

The risk of estimating the deterministic value of the contract, amounting to $49.80 \%$, may mean the necessary cost contingency at the level of:

$$
\text { 1,756,577.17 PLN * 0.498 = 874,775.4307 PLN }
$$

\section{Discussion}

Positive aspects related to a small hydroelectric power plant, in particular, are revealed at the stage of its operation, in the form of financial profits for the investor and environmental protection through the production of "clean" energy, that is using a renewable source, while not emitting harmful substances into the atmosphere.

The advantage of small hydroelectric power plants compared to other renewable energy sources is the stability of energy generation. In addition, they do not 
require high levels of water, and the design and assembly time is short. Small hydroelectric power plants can be built without harm to the environment, including fish migration.

However, for an investment to be successful, a tedious and risky construction process should be carried out. A large number of permits, agreements and other documents necessary to be completed by the investor, before the commencement of construction works, is the first of the factors affecting the risk level of costs of construction projects. The level of bureaucracy affects the duration of the construction process, and this adversely affects the accuracy of predictions, including those of costs.

The use of the COMAR- Jarek Górecki program gives the opportunity to predict the level of risk of costs of a construction project and to calculate the value of the cost contingency. It can be used to determine the possible value of the contract at a reliable level. The expected construction costs are probabilistic in nature and can be determined at a given level of probability. The problem of predicting these costs comes down to looking for the most likely value - modal value - for the distribution of construction costs, calculated in the subsequent iterations of the computer simulation.

Calculated in the course of computer simulations, the value of the risk of estimating the costs of building a small hydroelectric power plant indicates that in almost every case the pre-calculated costs of the investment project will be exceeded. Therefore, it is necessary to provide investors with such co-financing mechanisms to minimize the investment risk of projects that, apart from their commercial nature, bring many benefits in the field of ecology.

The implementation of small hydroelectric power plants is a long-term investment of capital in a certain source of income. An additional advantage of a small hydroelectric power plant is its low maintenance costs incurred in the life cycle of the facility. Despite many difficulties at the preparatory stage, and later also the implementation stage, the investment result is visible for several decades both visually in the form of an elevated structure, as well as financially (revenues from electricity sales) and ecologically (production of "clean" energy). Due to the above-mentioned aspects, the profitability prospects are extensive, although the benefits presented fully encourage the discussion about the need to build small hydro power plants in Poland.

\section{References}

1. G.A. Aggidis, E. Luchinskaya, R. Rothschild, D.C. Howard, Renew. Energy, 35, 2632-2638, (2010)

2. S.K. Singal, R.P. Saini, C.S. Raghuvanshi, Energy Sustain. Dev., 14, 117-126, (2010)

3. G.L.T. Filho, I.F.S.D. Santos, R.M. Barros, Renew. Sustain. Energy Rev., 77, 229-238, (2017)

4. J. Tymiński, Wykorzystanie odnawialnych źródet energii $w$ Polsce do 2030 roku - Aspekt energetyczny $i$ ekologiczny [Usage of renewable energy sources in Poland until 2030 - Energy and ecological aspect] (Wydawnictwo IMBER, 1997)

5. S. Michałowski, J. Plutecki, Energetyka wodna, [Hydropower] (Wydawnictwa NaukowoTechniczne, 1975)

6. W. Jarocki, Budownictwo Wodne część II - budowle wodne [Water structures - part II] (Państwowe Wydawnictwo Rolnicze i Leśne, 1963)

7. S. Gołębiowski, Z. Krzemień, Przewodnik Inwestora Matej Elektrowni Wodnej [Investor's Guide to a Small Hydroelectric Power Plant] (Fundacja Poszanowania Energii, 1998)

8. W. Jabłoński, J. Wnuk, Zarządzanie Odnawialnymi Źródłami Energii. Aspekty ekonomiczno-techniczne, Wydanie II rozszerzone [Management of Renewable Energy Sources. Economics and technical aspects, Second Edition extended (Oficyna wydawnicza „Humanitas”, 2009)

9. A. Chochowski, F. Krawiec, Zarzadzanie $w$ energetyce. Koncepcje, zasoby, strategie, struktury, procesy $i$ technologie energetyki odnawialnej [Management in energy sector. Concepts, resources, strategies, structures, processes and technologies of renewable energy] (Wydawnictwo Difin, 2008)

10. M. Hoffmann, Małe elektrownie wodne - poradnik [Small hydropower plants - a guide] (Wydawnictwo Nabba Ltd., 1992)

11. M. Chudecki, Elektrownie Wodne w Gródku i Żurze - cenne elementy krajobrazu kulturowego Wdeckiego Parku Krajobrazowego [Hydroelectric Power Plants in Gródek and Żurze - valuable elements of the cultural landscape of the Wdecki Landscape Park] (Wydawnictwo Unitex, 2016)

12. A. Bańkowska (et al.), Słownik Języka Polskiego, Tom II L-P [Polish Language Dictionary, Volume II LP] (Państwowe Wydawnictwo Naukowe, 1979)

13. J. Górecki, Przegl. Bud., 2, 45-50 (2013)

14. J. Górecki, O potrzebie szacowania ryzyka kosztów przedsięwzięć budowlanych, [in:] Badania i analizy wybranych zagadnień $z$ budownictwa, Prace naukowe doktorantów, praca zbiorowa pod red. Joanny Bzówki [On the need to estimate the risk of costs of construction projects, [in:] Research and analysis of selected issues in construction, PhD thesis, collective work edited by Joanna Bzówka] (Wydawnictwo Politechniki Śląskiej, 2011) 